\title{
UDC 1.17.177.9
}

\author{
T. V. PODOLSKA ${ }^{1 *}$, O. I. SKRYL ${ }^{2}$ \\ ${ }^{1 *}$ V. N. Karazin Kharkiv National University (Kharkiv), e-mail tetyanapodolska@karazin.ua, ORCID 0000-0003-1159-7538 \\ ${ }^{2}$ V. N. Karazin Kharkiv National University (Kharkiv), e-mail wswan20@gmail.com, ORCID 0000-0002-1089-463X
}

\section{VOICES-POSITIONS IN DISCOURSES: HOW IS IDENTITY POSSIBLE?}

The article is devoted to the question of identity of a modern man which constantly emerges as a powerful wave and is brought up to date with new force. Thus, continuing scientific research on identity and individual identity are being held, but from a different point of view, i.e. by using modernized methodology. The purpose of the research is to substantiate scientific approaches, epistemological coordinate changes, and critical trends in the issue of identity that would allow solving the problems of nature of a modern person being. In this respect the narrative approach is considered to be up-to-date. Methodology. Interdisciplinary research perspective allowed using a comprehensive methodology where, complementing each other, there are phenomenological, cultural, anthropological, hermeneutic, systematic, historical and genetic methods and method historical-philosophical and socio-cultural comparative studies. Originality. Personal being occurs in time, and it's the narrative method, the main feature of which is its temporality and extension, that can involve all of us to self-understanding on the basis of certain turning points in our history. The compliance with relevant ethical standards in dealing with other people, and requirements of certain supra-individual structures properly correlates with our least resistant inner world view and outlook. As the narrative identity exists in the subjective sense of time, experience and understanding of the events of life, thus, despite the ontogenetic secondary of the personal identity with respect to the social one, the domination of the former one is more probable. Conclusions. The adoption of such an understanding of identity by everyone signifies a high degree of responsibility for self-constructing, which implicitly assumes not just to say "I", but first of all to define your being as a certain social debt: to another person, to society, its history and everyday life through which we get a chance to be happy.

Keywords: identity; discourse; narrative; narrative identity; everyday life; communication; communicative and discourse practices; responsible selfness

\section{Introduction}

In the context of modern both internal changes in society and civilization progress, the state of personal being can be described as permanent "jelly-like" one. Recent years have been testing our soul and consciousness in terms of understanding the answers to the question "Where are we from?", "Who are we?" and "Where are we going to?" Under pressure of many circumstances our being sometimes shudders when seeking for at least temporarily stable ground, and sometimes transfers into some suspension state.

Under such conditions, one can observe the destruction for structural self-reflection and psychosocial identity, because the latter can be understood as a subjective feeling while objectively observable quality of self-identity and integrity of the individual "ego", accompanied by a belief in identity and integrity of a particular image of the world and a man which it shares with others. The psychological aspect of our identity in connection with social certainty suffers primarily because we consciously and unconsciously try to find a support point on the ground that is slipping from under the feet and carries the person into the unknown, frightening world.
It is agreed that the ability to improve is the only quality with no alternative which nature endowed the human race. Thus, self-transformation is the basis of human nature and the only property common to all people. The question is how it is possible to make this self-constructing? Does it make sense?

It is worth mentioning the well-grounded statement of the "liquid modernity" researcher Z. Bauman. We know that in his writings he stated that in our contemporary age the relationship between the individual and society is changing because the concepts of identity, individual and individuality are becoming meaningless [2].

However, they (the concepts) remained in scientific discourse, because it (the scientific discourse) is seen today as a kind of narrative culture. S. Huntington correctly said about the inevitability of identity that it is like a sin: we could resist it but we can't avoid it. Giving the definition of this concept, he concludes that identity correlates with images of individuality and distinctiveness ("selfness"), which are shown by an actor, and formed (and change over time) due to the relationship of a man and significant characters around him [1919, p.181; 6]. 
Probably social being makes us flexible in the transformation of existing or designing new concepts constituted to explain the essence of personal being. Thus, continuing scientific research on identity and individual identity are being held, but from a different point of view, by using modernized methodology. Therefore, the question of identity of a modern man constantly emerges as a powerful wave and is brought up to date with new force.

\section{Purpose}

The purpose of the research is to substantiate scientific approaches, epistemological coordinate changes, and critical trends in the issue of identity that would allow solving the problems of nature of a modern person being. In this respect the narrative approach is considered to be up-to-date.

\section{Theoretical basis and results}

It is well known that a postmodern man freely operates arbitrary segments of not connected worldviews, discourses, and languages. In the realm of the spirit there are no limits, no targets, no milestones. Postmodern is characterized by passivity as a social integration strategy is replaced by the strategy of individual hallucinations. Since reaching the peak of individualism in postmodern one can say about the emergence of a new identity - humanity [6, p.262263 . Thus, the analysis of post-modern society leads to the conclusion about the "critical trend change" for avoiding such dissolution of personal identity within social one.

Awareness of human questions of today, in our opinion, should be based on the original postulate about the change of subject-centered reason by communicative reason that was reasonably argued by the prominent philosopher J. Habermas [18, 20]. Indeed, in the context of modern social and cultural space and specificity of "life-world" of a person it is the communicative reason that becomes a worthy successor.

Ch. Taylor states that nature that awakes our feelings is not tied to our concept of meaningful intelligence. It is no longer considered the system, which determines our rationality, but rather that defining for us the goals and abilities that we seek within ourselves. Now the action of nature is to awaken them, it may awaken in us a feeling of overwhelming opposition regulated control of analytical mind, establishing order, and this mind now is understood as subjective and procedural capacity [16, p.395].

In our polyphonic world where human has to play many voices-positions, to perform the continual exchange of information from different ego-worlds, one can say about the formation of a complex, multilevel selfness, identity as a process that lasts during the lifetime. With the change of mind we observe the changes in the gravitational center of selfness.

This important aspect is that a man turns to be a creature that is constantly looking for himself and that in every moment of his existence checks the conditions of his existence. Only dialogue or dialectical thought can help to understand human nature.

Similar statements are also key points in the dialogic philosophy of M. Bakhtin, who formulated the idea of "out of man existence" under which the real "ego" at the point of human disagreement with himself, his identification with the "other". His formula "all alone" is explains it comprehensively. Thus, the existence of individual "ego" suggests a situation of "out of man existence" and the communication refers to the deep structure of a personality $[6$, p.28].

In such circumstances, the presence of the Other is an obligatory condition of our identity, since no communication and discourse (even virtual) are impossible without it. The Other represents a subjective existential structure (another "ego") and objective existence (social space).

Outlining the problematic situation, to understand which N. Elias seeks in his work "Society of Individuals", the author says that we are now more interested in what we differ (personal identity) than what we have in common (social identity). But to reconcile this vicious circle the author later concludes that without identity, people will have no self-identity. The balance between these two notions can fluctuate in either direction [21, p.256].

We know that today rapidity of socio-cultural and global changes is pushing us to understanding identity as a mobile, multiple structure, depending on the context and interpreted rather as a process of permanent constructing rather than a final destination of self-comprehension. Thus, it is not so much about "who we are" and "where are we from" but much of what can become, how others imagine us and how it relates to our own ideas about ourselves when identities are created in the process of representation and not beyond it. 
Our identity as a process of designing, starting and finishing point of which is at the same time symbolic space of a socio-cultural reality, intricacies of discourses revealed to be new (in sense of hermeneutic), created every time. Just as there is a multiplicity of truths of the text, multiplicity of identities is also created and, or it will be better to say, multiple identity depending on the social context, the interpretation of life text.

Such a perspective view of understanding the identity somehow increases hermeneutic interpretation, which is reduced to the procedures for understanding consciousness more. Outlining the fact that the text of our life is the product of involvement in public space of intersubjectivity, we rather agree with Habermas' approach that our every action is communicative in nature, i.e. the language is the beginning of consciousness from the very beginning [18].

Mastering the languages of human communication enables us to become equal people able to understand ourselves. We agree with Charles Taylor that under the "language" one should consider not just a set of words, but indeed all means of self-expression. It is clear that mastering these languages is through communication with others, with "significant others" because no one learns languages necessary for selfidentity face to face with himself $[17$, p.30].

Thus, communication problems as space of many interactions, crossing of dialogues and discourse as a rational and communicative action logically arise. The main purpose of the latter, in particular, can be considered as proof of constructive engagement towards consensus on rational grounds the ethical aspects of social and cultural relations.

As there is a multiplicity of text truths, in the same way a plurality of identities or multiply identity depending on the social context, text interpretation of life is created. In this context the narrative method usage becomes the main one in analyzing identity. Narrating is a means by which "ego" is individualized, and its actions are identified. Through a narrative method we can ascribe authorship of actions to someone as in our actions (which includes speech acts) personality gets the best way of manifestation. It may be logically concluded that there is a plurality of individual identity.

Indeed, in the modern humanities narrative method has become very popular and productive due to the ability to explain the mechanisms for constructing social reality. With genetic roots in historiography, it gradually spread to linguistics, sociology, psychology, etc. J. Brokmeier and R. Harre say that the growth of interest in the study of narrative means the emergence of another kind of desire for a new paradigm and further improvement of post-positivist method in philosophy of science [3, p.29; 24].

The effectiveness of this method in practice is proved by a number of psychoanalytic research of a personality through narrative texts $[26 ; 27 ; 29 ; 30]$. The situation of the gradually shift and dissolution of boundaries between history and story can be also considered the impetus for deeper study of this concept. Moreover, it certainly requires scientific reflection by historians and narrative philosophers $[22 ; 23 ; 32]$.

Our main scientific researches are dedicated to the study of narrative identity from a new angle $[11 ; 12$; $13 ; 31]$.

Comparing methodological potential of concepts of discourse and narrative it is stated that discourse as a special way of communicating and understanding of the surrounding world is based, primarily, on the means of language, which is a connecting surface between language and reality. Discourse can be understood as a certain text with context that is culturally and historically determined. Every science is characterized by the relevant discourse, a number of values formed during a period of development and which is common in use. As for the narrative, it can be explained as a certain "manual" on the construction of reality based on personal limits of socio-cultural involvement of personality. The offer to construct a certain algorithm of reality from the perspective of the narrative based on a set of values for its understanding and constructing that is offered by the existing discourse. Narratives are the main means of selfunderstanding, of giving sense to human actions, at least through the organization of key life events that seem unrelated, as a whole. Narratives are sensitive to the time mode of human existence. They arrange our experience in time, events and activities into a single time image and plot, and this, of course, is impossible without proper speech techniques. Although the narrative can be interpreted as a subtype of discourse concerning methodological potential depth, understanding of past events role in the design of present and future perspectives, taking into account the temporal characteristics of being the use of the concept of narrative is more preferable.

It is clear that the famous "linguistic turn" gave extraordinary impulse to consider a number of problems of philosophy, sociology, psychology, cultural 
studies through their speech explication. We agree that cognitive functioning of various practices in the sphere of natural science as well, may be possible only through their presentation in the narrative as the story has moved beyond its disciplinary limits (narratology). Within the linguistic interpretation the narrative is appropriate to be understood as a certain epistemological category, as a method that is able to combine language and time issues. To sum up it should be noted that the content of the story can not exist independently, and its narrative is able to make it independent, to provide integrity, to link the structure, form and objectives of oral or written representation of the narrative by different means [10].

It is also important to emphasize that cognitive function of narrative is found out in the etymology of the term as it relates to gnarus (in Latin), meaning "one who knows, an expert". Returning to the abovementioned Ch. Taylor's point of view it is impossible to study a narration, a story, a narrative exceptionally as a text by means of language in today's world.

\section{Originality}

Personal being occurs in time, and it's the narrative method, the main feature of which is its temporality and extension, that can involve all of us to selfunderstanding on the basis of certain turning points in our history. The compliance with relevant ethical standards in dealing with other people, and requirements of certain supra-individual structures properly correlates with our least resistant inner world view and outlook. As the narrative identity exists in the subjective sense of time, experience and understanding of the events of life, thus, despite the ontogenetic secondary of the personal identity with respect to the social one, the domination of the former one is more probable. Thus, the problem of determining their social topos, social identity is less problematic and can be reduced to the presence of permanent ascription and copying certain statuses and roles with changing social and cultural contexts.

It is important that everyday life, its history are understood as layers of activity and objects of historical process and its subjects. Thus, we suppose that the potential of understanding of everyday life as a whole set of cultural and historical events, mental patterns and scenarios of life can be revealed, for instance, using the narrative method, because its possibilities can explain the dynamic models of human behavior, coordinating them with each other in the time continuum.
Our local repertoire of narrative forms are intertwoven with a broader set of cultural discourse orders that define who tells that story, where, when and to whom. The key unit of analysis here is an event that reflects the "co-being". Each of our story, that is a story about ourselves, is inextricably linked with our narrative identity. All the time the selection of the script that will be understandable to a particular individual, group, society is permanently made. In other words, the unity of our lives is the unity of narrative searching, and narrative identity can serve as an "individual mythology".

Narrative identity as comprehension of themselves along with others and for others in a temporal mode, best reveals its viability in communication, in a dialogue aimed at reaching an agreement. The projection of narrative identity on the culture of everyday life allows centering of selfness through "narrative gravity".

Most of our co-being with others is of socially normative character. However, those events that are outside regulations, have the key influence on the "narrative gravity" on the basis of features. In recent years for modern Ukrainians a usual hierarchy of social and normative events has been dramatically broken. As a result of occupation, war, migration the vast majority of people increasingly find themselves outside of sustainability actually or mentally. However, such non-standard events "shake" our narrative identity on the basis of the changed cultural conditions, discourse, speech patterns of selfcomprehension. Public actors "try on" a lot of masks, and more and more people are taken aback by the Kantian question "What shall I do?"

A. MacIntyre offers a man ask another question before this: "In what kind of history can I identify myself as part of it?" We are talking here about continuous (since birth) process of interiorization of many roles with only one goal - we must understand these characters (from Eng. "character") in order to understand how others react to us and how we respond to them $[9, \mathrm{p} .292]$. Ultimately, we not only learn how to understand the society in general, but ourselves as its part. There is no other way of acquiring understanding of any society, including our own, in addition to mastering many stories that make up the original dramatic source of society [at the same source].

In view of the above mentioned we made an attempt to explain the importance and urgent need to examine the issue of permanent (re)formation of 
personal nature understanding, the formation of personal identity in the context of the ethical foundations of modern communicative and discursive space. This approach is considered to be able to avoid irresponsibility in explaining the "human situation". It should be also noted that such an explanation pushes an individual to understanding of importance to be involved in public relations, because it's the communication where viability of identity is possible in the sense of coordination of events, narratives of life in a situation of constant absorption of many discursive models. The latter are based on the principles of communicative practical philosophy, require continuous production of ethical discourse, i.e. constant renovation of moral norms and principles of the communicative community, which turns to be the result of understanding the everyday life world, and along with this duly affects the understanding between its members and helps to reach consensus.

In this context ethical components of modern practical philosophy are relevant and urgent, because the situation of a person in modern society appears to be an ethical problem. In the list of factors that impact on such a situation one can see an urgent problem of responsibility of the individual for his words and actions as today "self-confinement" is the guarantee of our recognition in a set of communication ensembles. This in turn serves as a selfish human need in terms of understanding your own story and the opportunity of permanent inner peace that is almost exhaustively reached by narrative identity in communicative and discursive practices.

The definition of narrative identity as a story about ourselves in communicative interaction and its coordination with past experience of the individual makes the communication problematic, in which the ability of self-construction, the creation of an adequate picture of reality that is communicative and discursive space is possible.

Taking into account the above said, we can conclude that the proposal to address the issue of individual identity in the field of interpersonal interaction is based on:

- inability in historical and cultural perspective to think of yourself out of the correlation with the Other (human, social structure), as this mainly depends on all our formation as social beings;

- the availability of the surrounding world coordinate system that expresses indirect language and determines everyday life;
- dialogic nature of the individual as the most important existential characteristic;

- the need of constant testing of your subjective world in terms of its compliance (subjective world) with objective reality.

$\mathrm{H}$. Arendt convincingly focuses on the action that is understood as a communicative interaction and allows a person to be engaged in social context, and the world in general is the space created by people's actions and speeches. The action and the language are closely connected because any human act $a$ priori has the answer to the question "Who are you?" This reveals the nature of an acting person. Only if someone is able to understand the meaning of our words, as well as the purpose of our actions, we can say that the identity of "ego" was revealed [1]. An important conclusion is that a communicative action should start from defining backgrounds of understanding, so that it will acquire the right to call interaction, mutual influence between individuals.

The dialogue as a "connection movement" is the main principle of narrative identity that organizes it. It is understood quite broadly and is defined not only as communication, but also as mutual orientation of inner action. It is possible to understand the mystery of the other by dialogical communication.

K.-O. Apel, based on the statement that there is no person outside communication, accordingly explains the fact that every communicative act involves $a$ priori communicativeness, and communication in the way of implementation is an "ideal communicative community" [28]. Due to K-O. Apel, it is the principle of "a priori communication", the presence of moral and normative core of which is clear for all members of the community. Due to this, even before the act of direct interaction we have respect for someone with whom we have to communicate. And the started communication is motivated by the task to reach understanding with someone. The universal desire to see in everyone such a type is dictated by the purpose of proper communication.

The philosophical interpretation of communication, which is proposed here, allows explaining urgent definition of ethics, which is based on the implementation of conditions of intersubjective communication $[7 ; 8 ; 28]$. That is, to form ethical principles of discourse ethics that enables to prove rational justification of morality in society, and therefore to redefine the rules of self-confinement while constructing morally loaded identity. We agree with N. A. Busova, who says that communicatively acting actors focused 
on the coordination of action plans through the achievement along with others common understanding of the situation. Social integration is not the epiphenomenon of such an action, but a clearly marked function [4, p.154].

On this basis, we can assume that narrative identity in terms of desire to self-contracting with the goal of being constantly 'online', socially engaged, as a space for living, as "home of your being" is a communicative action, or, in our view, a communicative act. At the same time, the need of understanding and communication ethics make this space use such a strategy of self-understanding, comprehension identity due to which the social system will be able to keep a balance, excluding any possible manifestations of an identity crisis.

\section{Conclusions}

In conclusion, we may note that communication in the discourse is aimed at mutual understanding, therefore, subject-subject relationships need attention and respect to the Other. In order to be universal, it (communication) must be reasoned, rationally reasonable and self-conscious. Communicative action, as opposed to monologue unequivocal instrumentally rational action, is characterized by ambiguity and dialogic because it requires understanding of at least two participants [18]. We also emphasize the principles of reciprocity and responsibility in communication activities that combine the theory of discourse ethics, which explains moral reasoning mechanisms and supports communication in society. Thus, social function of communicative action is to create personal identity. In the context of practical philosophy of communication the theory of narrative identity appears to be the most appropriate to explain the problem of finding its own deep reliance, the meaning of which can not be revealed beyond communicative and discursive space of human existence.

Considering the theory of justice P. Ricoeur believes that "self" constitutes its identity in such a structure of relationship where dialogical dimension prevails over monologic that in terms of reflexive philosophy would be of primary importance. Thus, the ethical orientation of dialogical dimension, by $\mathrm{P}$. Ricoeur, takes place in the following aspects: focus on living well with others and for others in just institutions [14, p.15; 15]. Communicative discursive space initiates narrative identity, but its moral component is of primary importance in narrative identity [12].

Returning to the original identity in the context of which it seems necessary to consider ethical regulators of communication space in modern society it is important that identity is defined by obligations and identifications that in their turn create a frame or horizon, where a man can always try to determine what is good or value for me [16, p.44-45]. Feeling good should be a part of person understanding of his life as an unfolded story. It should be added that this "horizon", in our view, may be described as a plexus of communication forms, the usage of which leads to gaining recognition, achieving consensus and forming the constituents of post-conventional moral consciousness on the bases of which we will adhere to the norms of rational interaction, due to the internal motivation and, accordingly, be aware of our own responsibility for the words and actions in society. A person as a dialogue creature undoubtedly requires recognition from others, adequate understanding (perception) of personal identity, which is defined as one for theoretical explanations of communicative action, discourse ethics and communicative mind.

During the lifetime a real good for everyone can be encountering his own "footprints", i.e. recognition of the results of his own actions, once correctly understood, accepted behaviors and those that were continued. This success is defined as the best reward, the evidence of the true story of yourself, agreed with the events of life, about the correctly chosen narrative method in permanent construction of identity in all its manifestations. Actually, it can be considered to be the realization of narrative identity in a broad, socially significant sense. Talking about the urgent need in terms of provoking present situation to determine the moral basis of identity, narrative identity is worth mentioning. The adoption of such an understanding of identity by everyone signifies a high degree of responsibility for self-constructing, which is implicitly assumes just to say "I", and, above all, to recognize its being indebtedness, before others, society, its history and everyday life through which we get a chance to be happy. Starting to construct selfness, a person thus creates a solid foundation of prospective functioning of a social system as a principal, in our view, a certain small narrative of responsibility. 


\section{LIST OF REFERENCE LINKS}

1. Арендт, Г. Становище людини / Г. Арендт [пер. с англ. М. Зубрицька]. - Львів : Літопис, 1999. - 255 с.

2. Бауман, 3. Текучая современность / З. Бауман [пер. с англ. под ред. Ю. В. Асочакова]. - Санкт-Петербург : Питер, 2008. - 240 c.

3. Брокмейер, Й. Нарратив : проблемы и обещания одной альтернативной парадигмы / Й. Брокмейер, Р. Харре [пер. с англ. Е. А. Мамчур] // Вопросы философии. - 2000.- № 3. - С. 29-42.

4. Бусова, Н. А. Юрген Хабермас о становлении коммуникативного действия / Н. А. Бусова // Вопросы философии. - 2006. - № 10. - С. 153-165.

5. Вилков, В. Ю. Детерминанты американской идентичности и общности: теоретическая модель С. Хантингтона [Electronic resource] / В. Ю. Вилков, А. А. Погорелый // European cooperation. - 2015. - Vol. 6(6). - P.18-35. - Available at: http://we.clmconsulting.pl/index.php/we/article/download/76/287. - Title from the screen. - Accessed: 11.06.2017.

6. Воропай, Т. С. В пошуках себе. Ідентичність та дискурс / Т. С. Воропай. - Харків : ХДПУ, 1999. - 418 с.

7. Єрмоленко, А. Етика дискурсу Карла-Отто Апеля у контексті українського суспільства за доби модернізації / А. Срмоленко // Філософська думка. - 2007. - № 5. - С. 104-124.

8. Срмоленко, А. М. Комунікативна практична філософія / А. М. Єрмоленко. - Київ : Лібра, 1999. - 488 с.

9. Макинтайр, А. После добродетели: Исследования теории морали / А. Макинтайр; [пер. с англ. В. В. Целищева]. - Москва : Академический Проект; Екатеринбург : Деловая книга, 2000. - 384 с.

10. Мельникова, О. Т. Дискурсивный подход к исследованию идентичности / О. Т. Мельникова, Е. С. Кутковая // Вестник Московского Университета. Серия 14. Психология. - 2014. - №1. - С. 59-71.

11. Подольська, Т. В. Відповідальна ідентичність сучасної людини / Т. В. Подольська // Наукові записки Національного університету «Острозька академія». Серія «Культурологія» Проблеми культурної ідентичності в ситуації сучасного діалогу культур: Матеріали IX міжнародної наукової конференції (2021.05.2016). - Острог, 2016. - Вип. 17. - С. 298-300.

12. Подольська, Т. В. Моральний вимір ідентичності в просторі комунікації / Т. В. Подольська // Вісник Харківського національного університету імені В. Н. Каразіна. Серія : філософія. Філософські перипетії. 2008. - № 830. - C. 192-199.

13. Подольська, Т. В. Соціально-філософський аналіз наративної ідентичності: автореф. дис. на здоб. наук. ступеня канд. філос. наук : 09.00.03 - соціальні філософія та філософія історії / Подольська Тетяна Василівна ; Харк. нац. ун-т імені В. Н. Каразіна. - Харків, 2010. - 18 с.

14. Рікер, П. Право і справедливість / П. Рікер [пер. із фр]. - Київ : Дух і Літера, 2002. - 216 с.

15. Рікер, П. Сам як інший / П. Рікер [пер. із фр.]. - Київ : Дух і Літера, 2000. - 458c.

16. Тейлор, Ч. Джерела себе. Творення новочасної ідентичності / Ч. Тейлор [пер. $з$ англ.]. - Київ : Дух і Літера, 2005. - 696c.

17. Тейлор, Ч. Етика автентичності / Ч. Тейлор [пер. з англ.]. - Київ : Дух і літера, 2002. - 128c.

18. Хабермас, Ю. Моральное сознание и коммуникативное действие / Ю. Хабермас [пер. с нем., под ред. Д. В. Скляднева]. - Санкт-Петербург : «Наука», 2000. - 379 с.

19. Хантингтон, С. Идентичности национальные и прочие / С. Хантингтон // Глобализация и идентичность: Хрестоматия [сост. Т. С. Воропай]. - Харьков : Эксклюзив, 2007. - С. 180-193.

20. Шачин, С. В. Коммуникативная теория разума Юргена Хабермаса и ее применение к некоторым психологическим темам / С. В. Шачин // Культурно-историческая психология. - 2012. - №1.- С. 34-46.

21. Элиас, Н. Общество индивидов / Н. Элиас; [пер. с нем.]. - Москва : Праксис, 2001. - 336 с.

22. Adler, J. M. Living Into the Story: Agency and Coherence in a Longitudinal Study of Narrative Identity Development and Mental Health Over the Course of Psychotherapy / J. M. Adler // Journal of Personality and Social Psychology, 2012, Vol.102, no 2, pp. 367-389. doi: 10.1037/a0025289.

23. Benwell, B. Discourse and identity / B. Benwell, E. Stokoe. - Edinburgh : Edinburgh University Press, 2006. $314 \mathrm{p}$.

24. Brockmeier, J. Beyond the Archive: Memory, Narrative, and the Autobiographical Process / J. Brockmeier. Oxford : Oxford University Press, 2015. - 401 p. doi: 10.1093/acprof:oso/9780199861569.001.0001.

25. Castells, M. The Power of Identity: The Information Age: Economy, Society, and Culture [Electronic resource] / M. Castells. - Oxford : John Wiley \& Sons, 2011. - Vol. 2. - 584 p. Available at: https://deterritorialinvestigations.files.wordpress.com/2015/03/manuel_castells_the_rise_of_the_network_societyb ookfi-org.pdf - Title from the screen. - Accessed: 12.06.2017.

26. Lilgendahl, J. P. Constructing stories of self-growth: How individual differences in patterns of autobiographical reasoning relate to well-being in midlife / J. P. Lilgendahl, D. P. McAdams // Journal of Personality. - 2011. Vol. 79, No. 2. - P. 391-428. doi: 10.1111/j.1467-6494.2010.00688.x 
27. Margolis, J. Pragmatism's Advantage: American and European Philosophy at the End of The Twentieth century / J. Margolis. - Stanford : Stanford University Press, 2010. - 192 p.

28. McAdams, D. P. The Art and Science of Personality Development / D. P. McAdams. - New York : The Guilford Press, 2015. $-367 \mathrm{p}$.

29. McAdams, D. P. Narrative Identity / D. P. McAdams, K. C. McLean // Current Directions in Psychological Science. - 2013. - Vol. 22, Iss. 3. - P. 233-238. doi: 10.1177/0963721413475622

30. Podolska, T. V. To the question of narrativity of social being through temporal selfness / T. V. Podolska // Bicник Харківського національного університету імені В. Н. Каразіна. Серія : філософія. Філософські перипетії. 2014. - № 1116 - C. 55-62.

31. Ryan M.-L. Texts, Worlds, Stories: Narrative Worlds as Cognitive and Ontological Concept [Electronic resource] / M.-L. Ryan // Narrative Theory, Literature, and New Media: Narrative Minds and Virtual Worlds (Routledge Interdisciplinary Perspectives on Literature). - Oxford : Routledge, 2016. - P. 11-29. Available at: https://www.amazon.com/Narrative-Theory-Literature-Media-Interdisciplinary/dp/113885414X - Title from the screen. - Accessed: 12.06.2017.

32. The Coherence of Critical Event Narratives and Adolescents' Psychological Functioning / Y. Chen, H. M. McAnaly, W. Wang, E. Reese // Memory. - 2012. - Vol. 20, No 7, - P. 667-681. doi: 10.1080/09658211.2012.693934

\title{
т. В. ПОДОЛЬСьКА ${ }^{1 *}$, О. І. СКРИЛЬ²
}

\author{
1*Харківський національний університет імені В. Н. Карабіна (Харків), ел. пошта tetyanapodolska@ karazin.ua \\ ORCID 0000-0003-1159-7538 \\ ${ }^{2}$ Харківський національний університет імені В. Н. Карабіна (Харків), ел. пошта wswan20@gmail.com, \\ ORCID 0000-0002-1089-463X
}

\section{ГОЛОСИ-ПОЗИЦІї В ДИСКУРСАХ: ЯК МОЖЛИВА ІДЕНТИЧНІСТЬ?}

Стаття присвячена питанню ідентичності сучасної людини, яке повсякчас виринає як потужна хвиля та актуалізується з новою силою. Отже, тривають наукові розвідки з питань ідентичності, індивіда та індивідуальності, проте під іншим кутом зору, використовуючи осучаснену методологію. Мета роботи полягає в обгрунтуванні таких наукових налаштувань, зміні епістемологічних координат, критичної тенденції у питанні ідентичності, що б дозволило вирішувати проблемні прогалини сутності буття сучасної людини. Щодо останнього саме наративний підхід вважається адекватним викликам часу. Методологія. Міждисциплінарна перспектива дослідження дозволила застосовувати комплексну методологію, в якій, взаємодоповнюючи один одного, представлені феноменологічний, культурно-антропологічний, герменевтичний, системний, історико-генетичний методи та метод історикофілософської та соціокультурної компаративістики. Наукова новизна. Персональне буття людини перебігає в часі, і саме наративний метод, головною особливістю якого визначається його темпоральність, протяжність, здатен долучити кожного 3 нас до саморозуміння на підставі впорядкування певних поворотних пунктів в нашій історії. Дотримання відповідних моральних норм у стосунках з іншими, вимог певних надіндивідуальних структур належним чином корелює 3 нашим бодай наймеш стійким внутрішнім світосприйняттям і світорозумінням. Оскільки наративна ідентичність існує в плані суб'єктивного часу, переживання та осмислення подій життя, то, незважаючи на онтогенетичну вторинність особистісної ідентичності по відношенню до соціальної, ймовірним є домінування першої. Висновки. Прийняття такого розуміння ідентичності кожним знаменує високий ступінь відповідальності щодо конструювання самості, яка вже імпліцитно передбачає навіть не просто говорити «Я», а, перш за все, визнавати своє буття як певну заборгованість перед іншим, суспільством, власною історією та повсякденністю, завдяки яким ми й отримуємо щасливу нагоду існувати.

Ключові слова: ідентичність; дискурс; наратив; наративна ідентичність; повсякденність; комунікація; комунікативно-дискурсивні практики; відповідальна самість 


\section{Т. В. ПОДОЛЬСКАЯ ${ }^{*}$, О. И. СКРЫЛЬ²}

${ }^{1 *}$ Харьковский национальный университет имени В. Н. Каразина (Харьков), эл. почта tetyanapodolska@karazin.ua, ORCID 0000-0003-1159-7538

${ }^{2}$ Харьковский национальный университет имени В. Н. Каразина (Харьков), эл. почта wswan20@gmail.com, ORCID: 0000-0002-1089-463X

\section{ГОЛОСА-ПОЗИЦИИ В ДИСКУРСАХ: КАК ВОЗМОЖНА ИДЕНТИЧНОСТЬ?}

Статья посвящена вопросу идентичности современного человека, который постоянно всплывает как мощная волна и актуализируется с новой силой. В связи с этим продолжаются научные исследования вопросов идентичности, индивида и индивидуальности, но под другим углом зрения, используя современную методологию. Цель работы заключается в обосновании таких научных настроек, изменении эпистемологических координат, критической тенденции в вопросе идентичности, что позволило бы решать проблемные пробелы сущности бытия современного человека. Что касается последнего, именно нарративный подход считается адекватным вызовам времени. Методология. Междисциплинарная перспектива исследования позволила применять комплексную методологию, в которой, взаимодополняя друг друга, представлены феноменологический, культурноантропологический, герменевтический, системный, историко-генетический методы и метод историкофилософской и социокультурной компаративистики. Научная новизна. Персональное бытие человека протекает во времени, и именно нарративный метод, главной особенностью которого определяется темпоральность, протяженность, способен привлечь каждого из нас к самопониманию на основании упорядочивания определенных поворотных пунктов в нашей истории. Соблюдение соответствующих моральных норм в отношениях с другими, требований определенных надындивидуальных структур должным образом коррелирует с нашим хотя бы сколь-нибудь устойчивым внутренним мировоззрением и миропониманием. Поскольку нарративная идентичность существует в плане субъективного времени, переживания и осмысления событий жизни, то, несмотря на онтогенетическую вторичность персональной идентичности по отношению к социальной, вероятным является доминирование первой. Выводы. Принятие такого понимания идентичности каждым знаменует высокую степень ответственности за конструирование самости, которая уже имплицитно предполагает даже не просто говорить «Я», а, прежде всего, признавать свое бытие как некий долг перед другим, обществом, собственной историей и повседневностью, благодаря которым мы и получаем счастливую возможность существовать.

Ключевые слова: идентичность; дискурс; нарратив; нарративная идентичность; повседневность; коммуникация; коммуникативно-дискурсивные практики; ответственная самость

\section{REFERENCES}

1. Arendt, H. (1999). Stanovyshche liudyny. Lviv: Litopys.

2. Bauman, Z. (2008). Tekuchaia sovremennost. Saint Petersburg: Piter.

3. Brockmier, J., \& Harre, R. (2000). Narrative: Problems and Promises of an Alternative Paradigm., 3, 29-42.

4. Busova, N. A. (2006). Iurgen Khabermas o stanovlenii kommunikativnogo deistviia. Voprosy filosofii, 10, 153165.

5. Vilkov, V. Y., \& Pogorelyi, A. A. (2015). Determinants of American Identity and Community: S. Huntington's Theoretical Model. European Cooperation, 6(6), 18-35. Retrieved from http://we.clmconsulting.p1/index.php/we/article/download/76/287

6. Voropai, T. S. (1999). V poshukakh sebe. Identychnist ta dyskurs. Kharkov: KhDPU.

7. Yermolenko, A. (2007). Etyka dyskursu Karla-Otto Apelia u konteksti ukrainskoho suspilstva za doby modernizatsii. Filosofska dumka, 5, 104-124.

8. Yermolenko, A. M. (1999). Komunikatyvna praktychna filosofiia. Kyiv: Libra.

9. Makintair, A. (1999). Posle dobrodeteli: Issledovaniia teorii morali. Moscow: Akademicheskii Proekt; Ekaterinburg: Delovaia kniga.

10. Melnikova O.T., \& Kutkovaya E.S. (2014). Discursive approach to identity research. Moscow University Psychology Bulletin. Series 14. Psychology, 1, 59-71.

11. Podolska, T. V. (2016). Vidpovidalna identychnist suchasnoi liudyny. Proceedings of the IX mizhnarodna naukova konferentsiia: Naukovi zapysky Natsionalnoho universytetu "Ostrozka akademiia». Seriia "Kulturolohiia» Problemy kulturnoi identychnosti v sytuatsii suchasnoho dialohu kultur, May 20-21, 2016, Ostrog, 17. Ostrog, 298-300. 
12. Podolska, T. V. (2008). Moralnyi vymir identychnosti v prostori komunikatsii. Visnyk Kharkivskoho natsionalnoho universytetu imeni V. N. Karazina. Seriia : filosofiia. Filosofski perypetii, 830, 192-199.

13. Podolska, T. V. (2010). Sotsialno-filosofskyi analiz naratyvnoi identychnosti. (PhD thesis). Available from V. N. Karazin Kharkiv National University, Kharkiv.

14. Riker P. (2002). Pravo i spravedlyvist. Kyiv: Dukh i Litera.

15. Riker, P. (2000). Sam yak inshyi. Kyiv: Dukh i Litera.

16. Teilor, C. (2005). Dzherela sebe. Tvorennia novochasnoi identychnosti. Kyiv: Dukh i Litera.

17. Teilor, C. (2002). Etyka avtentychnosti. Kyiv: Dukh i Litera.

18. Khabermas, I. (2000). Moralnoe soznanie i kommunikativnoe deistvie (D. V. Skliadneva Trans.). Saint Petersburg: «Nauka».

19. Khantington, S. (2007). Identichnosti natcionalnye i prochie. In T. S. Voropai (Ed.) Globalizatciia i identichnost Khrestomatiia (180-193), Kharkov: Ekskliuziv.

20. Shachin, S. V. (2012). Jurgen Habermas's Theory of Communicative Rationality and its Applications to Certain Psychological Issues. Cultural-Historical Psychology Journal, 1, 34-46.

21. Elias, N. (2001). Obshchestvo individov. Moscow: Praksis.

22. Adler, J. M. (2012). Living into the story: Agency and coherence in a longitudinal study of narrative identity development and mental health over the course of psychotherapy. Journal of Personality and Social Psychology, 102(2), 367-389. doi:10.1037/a0025289

23. Benwell, B., \& Stokoe, E. (2006). Discourse and identity. Edinburgh: Edinburgh University Press.

24. Brockmeier, J. (2015). Beyond the Archive: Memory, Narrative, and the Autobiographical Process. doi:10.1093/acprof:oso/9780199861569.001.0001

25. Castells, M. (2011). The Power of Identity: The Information Age: Economy, Society, and Culture. Vol. 2. Oxford : $\begin{array}{lllll}\text { John Wiley } \quad \text { \& } & \text { Sons. } & \text { Retrieved from }\end{array}$ https://deterritorialinvestigations.files.wordpress.com/2015/03/manuel_castells_the_rise_of_the_network_societyb ookfi-org.pdf - Title from the screen

26. Lilgendahl, J. P., \& McAdams, D. P. (2011). Constructing Stories of Self-Growth: How Individual Differences in Patterns of Autobiographical Reasoning Relate to Well-Being in Midlife. Journal of Personality, 79(2), $391-428$. doi:10.1111/j.1467-6494.2010.00688.x

27. Margolis, J. (2010). Pragmatism's Advantage: American and European Philosophy at the End of The Twentieth century. Stanford : Stanford University Press.

28. McAdams, D. P. (2015). The Art and Science of Personality Development. New York : The Guilford Press.

29. McAdams, D. P., \& McLean, K. C. (2013). Narrative Identity. Current Directions in Psychological Science, 22(3), 233-238. doi:10.1177/0963721413475622

30. Ryan M.-L. (2016). Texts, Worlds, Stories: Narrative Worlds as Cognitive and Ontological Concept. In Hatavara, M., Hyvärinen, M., Mäkelä, M., \& Mäyrä F. (Eds.) Narrative Theory, Literature, and New Media: Narrative Minds and Virtual Worlds (Routledge Interdisciplinary Perspectives on Literature) (11-29). Oxford : Routledge. Retrieved from https://www.amazon.com/Narrative-Theory-Literature-Media-Interdisciplinary/dp/113885414X

31. Chen, Y., McAnally, H. M., Wang, Q., \& Reese, E. (2012). The coherence of critical event narratives and adolescents' psychological functioning. Memory, 20(7), 667-681. doi: 10.1080/09658211.2012.693934

Ph.D., prof. I. Karpenko (Ukraine) recommended this article to be published

Received: Feb. 10, 2017

Accepted: May 20, 2017 